\title{
Nursing Activities Score by assistance sites in Intensive Care Units
}

\author{
Nursing Activities Score nos sítios assistenciais em Unidade de Terapia Intensiva \\ Nursing Activities Score en sitios asistenciales en Unidad de Cuidados Intensivos
}

\author{
Claudia Maria Silva Cyrino ${ }^{1,2}$ \\ Magda Cristina Queiroz Dell'Acqua² \\ Meire Cristina Novelli e Castro ${ }^{2}$ \\ Elaine Machado de Oliveira ${ }^{3}$ \\ Sérgio Deodato ${ }^{1}$
}

Priscila Masquetto Vieira de Almeida²

1. Universidade Católica Portuguesa.

Lisboa, Portugal.

2. Universidade Estadual Paulista.

Botucatu, SP, Brazil.

3. Universidade de São Paulo.

São Paulo, SP, Brazil.

Corresponding author:

Claudia Maria Silva Cyrino.

E-mail: claucyrino@gmail.com

Submitted on 05/21/2017.

Accepted on 10/04/2017.

DOI: 10.1590/2177-9465-EAN-2017-0145

\section{Abstract}

Objective: To compare the Nursing Activities Score (NAS) between the Assistance Sites in an Intensive Care Unit. Method: Descriptive, retrospective study, carried out in the Intensive Care Unit of a teaching hospital. The patients were organized in Assistance Sites according to their clinical characteristics and the nursing team's composition was organized in accordance with the Nursing Activities Score (NAS). The confidence interval was set at $p<0.05$. Results: the majority were male surgical patients with a mean age of 56.8 years. The postoperative care Site presented the greatest patient turnover. The overall average NAS was $71.7 \%$. There was a difference in the nursing workload between the different Assistance Sites. The shorter length of stay and the nonsurvivors contributed to increasing the workload in the ICU. Conclusion: Comparing the NAS in the different Sites made it possible to organize the work process of the nursing team according to each group, contributing to patient safety.

Keywords: Workload; Nursing; Organization and Administration; Intensive Care Unit.

\section{Resumo}

Objetivo: Comparar o Nursing Activities Score (NAS) entre os Sítios Assistenciais na Unidade de Terapia Intensiva. Método: Estudo descritivo, retrospectivo, realizado na Unidade de Terapia Intensiva de um hospital escola. Os pacientes foram organizados em Sítios Assistenciais, conforme suas características clínicas e o dimensionamento dos profissionais de enfermagem foi realizado de acordo com o NAS. Considerou-se $p<0,05$. Resultados: Predominaram-se pacientes do sexo masculino, cirúrgicos e com idade média de 56,8 anos. O Sitio Pós-Operatório apresentou maior rotatividade de pacientes. O NAS médio global foi 71,7\%. Verificou-se diferença da carga de trabalho de enfermagem entre os dias nos diferentes Sítios Assistenciais. O menor tempo de internação e os pacientes não sobreviventes contribuíram para aumentar a carga de trabalho na UTI. Conclusão: Comparar o NAS nos diferentes Sítios possibilitou organizar a dinâmica do processo de trabalho da equipe de enfermagem conforme a especificidade de cada grupo contribuindo para a segurança do paciente.

Palavras-chave: Carga de trabalho; Enfermagem; Organização e Administração; Unidade de Terapia Intensiva.

\section{Resumen}

Objetivo: Comparar el Nursing Activites Score (NAS) entre los Sitios Asistenciales en la Unidad de Cuidados Intensivos. Método: Estudio descriptivo, retrospectivo, realizado en la Unidad de Cuidados Intensivos de un hospital escuela. Los pacientes fueron organizados en Sitios Asistenciales según sus características clínicas y el dimensionamiento de los profesionales de enfermería fue realizado según el NAS. Se consideró $p<0,05$. Resultados: Predominaron pacientes del sexo masculino, quirúrgicos y con edad media de 56,8 años. El Sitio post-operatorio presentó mayor rotación de pacientes. El NAS medio global fue el $71,7 \%$. Se verificó diferencia de la carga de trabajo de enfermería entre los diferentes Sitios Asistenciales. El menor tiempo de internación y los pacientes no sobrevivientes contribuyeron con el aumento de la carga de trabajo en la UCl. Conclusión: Fue posible organizar el proceso de trabajo del equipo de enfermería de acuerdo con cada grupo, contribuyendo con la seguridad del paciente.

Palabras clave: Carga de trabajo; Enfermería; Organización y Administración; Unidad de Cuidados Intensivos. 


\section{INTRODUCTION}

Intensive Care Units (ICU) assist people with critical health situations and clinical instability for whom recovery is possible. These patients require continuous and comprehensive qualified medical and nursing care. ${ }^{1}$ These units are high cost, due to the use of advanced technology, differentiated physical space and highly specialized staff. ${ }^{2}$

ICUs are constantly evolving, and in recent decades have had to deal with an increase in patients with increasingly-serious clinical conditions - most of whom are elderly and with numerous comorbidities. These characteristics can have an impact on the number of interventions and on the nursing care. Consequently, they also impact on the work process and on the team's workload. ${ }^{3,4}$

Inadequate allocation of human resources is associated with the occurrence of adverse events, patient mortality, and increases in hospital costs. ${ }^{5}$ In this regard, one important challenge for the managers of these complex units is the nursing team's adaptation to these patients' care demands.

As a result, it is fundamental to apply an instrument for measuring the nursing workload in ICU so as to manage the care and the safety of the patients.

Among the instruments available for this purpose, the Nursing Activities Score (NAS) has been described as a reliable measure for assessing the nursing workload in intensive care, both in Brazil and abroad, as it encompasses $80.8 \%$ of the activities of nursing. ${ }^{6}$ These studies show the application of the NAS instrument in planning the interventions in accordance with each patient's real needs, assisting the nurses in deciding the composition and size of the nursing team and in the adaptation of the working practices and work process. ${ }^{3,7-10}$

The NAS, translated and validated for the Brazilian culture by Queijo, ${ }^{9}$ measures the nursing workload in ICU, in terms of the proportion of the time spent on direct and indirect care in the previous 24 hours. At the time of writing, this instrument is being used in 12 different countries and studies have related its use to variables such as patient mortality, length of stay, and the occurrence of adverse events. . $^{3,9,11,12}$

Using this instrument to measure the nursing workload promotes the practicing of safe care and reduces costs for the institution. ${ }^{7,10,11}$ Accordingly, the nurses must analyze the dynamics and specific characteristics of the ICU where they work, as well as the characteristics of the patients, in order to apply the tools and strategies for organizing the activities and the nursing work process.

In this regard, the Assistential Sites were implanted in this unit, the aim being to organize the care for the critically-ill patients in accordance with their clinical characteristics - and to adapt human resources according to the NAS score for each Site.

This proposal, which includes the organization of the care and the appropriate number of human resources for specific groups of patients, is related to reducing hospital infections, skin lesions or bedsores, the length of time in which the patient is dependent on mechanical ventilation, and length of stay in ICU. ${ }^{8}$
When one is aware of the care demands required by a group of patients with similar characteristics - principally through a tool which measures their needs - one is able to plan the resources and care which match these needs, which in turn contributes to the safety of the team and of the patient. ${ }^{8}$

This is the rationale for undertaking this study. Investigating the real needs of patients in the different Assistential Sites allows one, above all, to select an adequate composition of the nursing team in each Site - and consequently, the care provided to the inpatients.

As a result, the study's objective is to compare the nursing workload, as measured by the Nursing Activities Score, between the Assistential Sites, in the Intensive Care Unit.

\section{METHOD}

This is a descriptive, retrospective study, with a quantitative approach, undertaken in the General Intensive Care Unit of a teaching hospital in the non-metropolitan region of São Paulo, between first July and $21^{\text {st }}$ of October 2010.

The non-probabilistic sample of patients was made up of all of those who received care in ICU in the study period, excluding those patients who were there for less than 24 hours.

The clinical and demographic variables of the study were collected from the patients' medical records by the researchers. They included age, sex, length of hospitalization, and survivor or nonsurvivor. The NAS, as it is not yet part of the patient's electronic medical record, was scored daily by the unit's nurses using the computerized app in the ICU, developed by Castro ${ }^{13}$ in 2009.

The NAS instrument is made up of 7 categories: basic activities (monitoring and control, hygiene procedures, mobilization and positioning, support and care for family members and patients, administrative and managerial tasks), ventilatory support, cardiovascular support, renal support, neurological support, metabolic support and specific interventions; subdivided into 23 items, with variation between one, two and 32 points - and a maximum score of $176.8 \%$, representing $81 \%$ of the activities of nursing care. Items 1, 4, 6, 7 and 8 present self-excluding alternatives, in accordance with the variability of the requirements of the patient. ${ }^{6}$

\section{Study outline - Assistential Sites}

The patients were organized in three Assistential Sites, in accordance with the structure of the unit and the patients' clinical characteristics, these being:

- $\quad$ Postoperative Site (PO): with five beds, for patients with a maximum stay of 7 days post-surgery, as long as they were free of antibiotic-resistant infection.

- Isolation Site (I): with four beds, for patients with aerosol precautions or because they needed care involving hemofiltration. 
- $\quad$ Long Stay Site (LS): with six beds, for patients who had been treated for over 7 days in this ICU, or when they came from another unit in the institution, as well as patients with an antibiotic-resistant infection and contact precautions.

The ICU nursing professionals were organized in 3 teams by work shift in order to work at the three Assistential Sites. Each team was made up of one staff nurse and two nursing technicians, who worked at the same Assistential Site for a 10 day period and, once this period was over, moved on to the next Site, where they remained for a further 10 days, and so on.

In this way, the staff nurse was with the same nursing technicians at different Sites for the entire month, the purpose being to closen the personal contact and establish a teamwork dynamic between the members.

Besides these professionals, a further nursing technician, known as the 'floater', was present in each shift. This person was added to the team working at the Assistential Site with the highest workload as measured by the NAS. This strategy, characterized by the additional 'floating' nursing technician, was aimed at adjusting the composition of the nursing team in accordance with the needs of each group of patients.

In order to systematize the work process and promote the quality of the communication, a system was set up for indicating workload, developed by the ICU nurses, in accordance with the NAS score. Accordingly, the nurses responsible collected their patients' NAS, and, using the app's graphic representation capacity, this was printed at the end of data collection, and the patients classified according to the workload. A patient whose mean NAS was lower than $50 \%$ would receive, alongside their identification, a green sign - which indicated low workload. A patient with an NAS from $51 \%$ to $79 \%$ would receive a blue sign, indicating a medium workload, and a patient with an NAS above $80 \%$ would receive a red sign - which indicated high nursing workload.

The data were compiled in a Microsoft Office 2010 Excel spreadsheet and were analyzed using the Statistical Analysis System (SAS). Firstly, the descriptive statistics were undertaken, with absolute and relative frequencies for categorical variables, as well as means, standard deviation, medians and minimums and maximums for the quantitative variables and the NAS.

The Pearson correlation was used for the quantitative variables of age and length of stay, and variance analysis (ANOVA) was used for the qualitative variable of survivor or nonsurvivor.

In order to compare the variable of NAS, both in terms of time and of the Assistential Sites, the Mixed Model with repeated measures in time was undertaken, with interaction in relation to time v. Assistential Sites, with the Tukey adjustment, using the PROC MIXED from the SAS program.
For all the statistical tests, $p<0.05$ was considered as the level of significance.

The project was approved by the Research Ethics Committee of the Faculty of Medicine of Botucatu (UNESP), in accordance with Resolution 466 of Brazil's National Health Council, 2012, ${ }^{14}$ under number OF. 257/2010.

\section{RESULTS}

The study's sample was made up of 214 patients of whom $63.0 \%$ were male, $71.0 \%$ were surgical patients, the majority of whom were from the neurosurgical speciality $(27.6 \%)$, and of whom $27.1 \%$ did not survive.

In relation to the distribution of the patients in the Assistential Sites, $57.0 \%(n=122)$ were patients at the Postoperative Site, this being the Assistential Site with the highest turnover, followed by the Isolation Site, with $34.6 \%(n=74)$ of the inpatients and the Long Stay Site, with $8.4 \%(n=18)$ of the inpatients - this last being the Assistential Site with the largest number of chronicallyill patients with a longer period of hospitalization in ICU - with a mean of 19.3 days.

Table 1 shows the distribution of the patients in ICU in relation to age, length of stay (LOS) in ICU and the NAS. It was ascertained that the mean global age of the patients hospitalized in ICU was 56.8 years old, with a mean stay in ICU of nine days, and a mean NAS of $71.7 \%$, varying from $48.2 \%$ to $109.1 \%$.

Table 2 compares the mean NAS value of the patients who survived and who did not survive through ANOVA variance analysis. The patients who ultimately did not survive required a higher workload of the nursing team $(79.9 \%)$, with a statistically significant difference.

Table 3 presents the correlation between the NAS and age and length of stay in ICU. Through the Pearson correlation text, it was ascertained - in this sample - that the NAS presented a negative correlation with length of stay in ICU (-0.23). Regarding the age of the patients, there was no statistically significant correlation $(p=$ 0.070 ) to assert that age influenced the nursing workload in ICU.

The distribution of the NAS over the months in which the study took place, and by Assistential Site, is shown in Table 4. It can be seen that the highest average NAS was found in the Postoperative Site, in the month of September, followed by the Isolation Site in the month of August. However, the values of the nursing workload remained constant over the four months analyzed.

In Table 5, which presents the distribution of the NAS by the days of the months analyzed, between the Assistential Sites, one can see that in the months of July and August, there was a statistically significant difference between the Isolation and Long Stay Sites. In September, the was a difference between the Long Stay and Postoperative Sites. In October, there was no statistically significant difference between the days in the different Assistential Sites. 
Table 1. Descriptive measures of the patients in relation to age, length of stay in ICU and NAS. Botucatu, 2010. $(n=214)$

\begin{tabular}{lccccc}
\hline $\begin{array}{l}\text { Quantitative } \\
\text { variables }\end{array}$ & Mean & Standard deviation & Median & Minimum & Maximum \\
\hline Age & 56.8 & 18.5 & 60.0 & 16.0 & 92.0 \\
\hline LOS & 9.2 & 13.3 & 4.0 & 1.0 & 93.0 \\
NAS & 71.7 & 10.4 & 69.8 & 48.2 & 109.1 \\
\hline
\end{tabular}

LOS: length of stay; NAS: Nursing Activities Score.

Table 2. Comparison of the NAS with the outcome of survival or nonsurvival of the patients. Botucatu, 2010

\begin{tabular}{lccc}
\hline NAS & $(\%)$ & $\begin{array}{c}\text { Standard } \\
\text { deviation }\end{array}$ & $\boldsymbol{p}^{*}$ \\
\hline Survivor & 68.4 & 7.3 & \\
Non-survivor & 79.9 & 12.3 & $<0.001$ \\
\hline * ANOVA.
\end{tabular}

Table 3. Analysis of the correlation of NAS with age and length of stay in ICU. Botucatu, 2010

\begin{tabular}{lcc}
\hline NAS & $\mathbf{R}$ & $\boldsymbol{p}^{*}$ \\
\hline Age & 0.12 & 0.070 \\
Length of stay in ICU & -0.23 & $<0.001$ \\
\hline * Pearson correlation. & &
\end{tabular}

Table 4. Distribution of the NAS by Assistential Sites, and by month. Botucatu, 2010

\begin{tabular}{|c|c|c|c|c|c|}
\hline \multirow{2}{*}{ Assistential Sites } & \multicolumn{4}{|c|}{ NAS } & \multirow{2}{*}{$p^{*}$} \\
\hline & July & August & September & October & \\
\hline 1 & $71.6 \%$ & $72.4 \%$ & $70.9 \%$ & $68.5 \%$ & 2.693 \\
\hline $\mathrm{PO}$ & $68.0 \%$ & $68.3 \%$ & $72.5 \%$ & $70.7 \%$ & 3.389 \\
\hline
\end{tabular}

I: Isolation; LS: Long Stay; PO: Post-operative; NAS: Nursing Activities Score.

Table 5. Comparison of the NAS measurements between the Assistential Sites by month. Botucatu, 2010

\begin{tabular}{|c|c|c|c|c|}
\hline Assistential Sites & \multicolumn{4}{|c|}{$p^{*}$} \\
\hline I-LS & 0.001 & 0.029 & 0.243 & 0.992 \\
\hline I-PO & 0.560 & 0.328 & 0.997 & 0.993 \\
\hline PO-LS & 0.567 & 0.998 & 0.015 & 0.514 \\
\hline
\end{tabular}

* Tukey. I: Isolation; LS: Long Stay; PO: Post-operative; NAS: Nursing Activities Score.

\section{DISCUSSION}

The study compares the nursing workload measured using the NAS between the different Assistential Sites, in an Intensive Care Unit in a teaching hospital.

The surgical specialty, and male gender, were prevalent in the sample studied. These results have also been identified in other studies. ${ }^{4,7,8,13,15}$ The mean age was 56.8 years old, and this is also consistent with other studies undertaken in Brazil. ${ }^{4,7,16}$ and abroad ${ }^{10,11,17}$

In relation to the outcome of survival or nonsurvival of the patients, it may be observed that $27.1 \%$ of the patients did not, ultimately, survive. In other studies undertaken in Brazilian ICUs, the mortality rate was $41.0 \%{ }^{2}$ and $21.6 \%,{ }^{4}$ while in studies undertaken in ICUs abroad, this value is close to $10.0 \% .^{8,17}$
It may be considered that the non-survival rate, at close to $27.0 \%$, found in the present study, may result from the association of different variables - such as preexistent chronic illnesses or the extensive length of stay in ICU, and the consequent Healthcare Associated Infections (HCAI). This result may be found in previous research carried out by Cyrino, ${ }^{18}$ which assessed the implantation of the Assistential Sites, the nursing workload, and the relationship of these with hospital infections. This fact may be explained by the chronic characteristics of the patients receiving inpatient treatment in ICU, particularly on the Long Stay Assistential Site, evidenced by a mean stay of 19 days.

The mean general length of stay in ICU was 9.2 days and was similar to that found in other Brazilian contexts. ${ }^{2,15}$ However, one coronary ICU in the South of Brazil had a median length of stay in the unit of 2 days, ${ }^{7}$ similar to the international mean of 4.82 days in one Italian teaching hospital ${ }^{17}$ and to 3.6 days in Spain. ${ }^{8}$ 
As to the mean NAS value of $71.7 \%$, one can observe a similarity with other Brazilian findings with means of $74.4 \%{ }^{2}$ and $71.0 \%,{ }^{16}$ both found in ICUs in high complexity public hospitals. In the ICU in the present study, in 2009, the mean NAS was lower, at $60.3 \%$ - varying from $27.8 \%$ to $123.1 \%,{ }^{13}$ indicating an increase in the complexity of the care and in the workload in the nursing care in this unit in recent years.

Recently, one multicentric study ${ }^{11}$ carried out in seven countries, with the aim of describing the workload in ICU using the NAS, identified variation in the scores, with means ranging from $44.5 \%$ in Spain through to $101.8 \%$ in Norway. The characteristics of the patients, the structure of the unit and the work process used in the different countries may explain the difference in mean NAS between these ICUs. ${ }^{10,11,19}$

In this regard, it can be said that the nursing workload is complex and nonlinear, and may be influenced by characteristics both of the nurses and of the patients, as well as the unit's organizational characteristics and by the time and effort necessary for carrying out the care provided. ${ }^{19}$

In relation to the clinical variables and the nursing workload in this sample, one can say that the shorter the length of stay, the higher the NAS. Regarding the outcome of survival or nonsurvival, the patients who ultimately had the outcome of death also presented a higher NAS than those who were discharged from the unit.

These results show a high workload for these two groups of patients, and it is considered that the care related to receiving the patient in a critical care unit or - on the other hand - when death is imminent, transcends the technical-assistential axis, with other activities becoming necessary, such as supporting the family and carrying out administrative arrangements.

On the other hand, age did not present a statistically significant correlation with NAS. One study undertaken with the aim of relating NAS in two different age groups among patients over 18 years old in ICU found that the elderly patients (over 60 years old) have a higher nursing workload in comparison with the adult patients; however, age, as it represented a very low portion of the workload and in the NAS score, had no discrimination ability as a good independent predictor of high workload in ICU. ${ }^{4}$

In relation to the NAS in each Assistential Site, it was verified that the highest mean NAS was found in the Postoperative Site in the month of September. This was where the patients requiring pre-and post-surgical care, from various surgical specialties, were treated.

When the NAS was compared between the Assistential Sites, the results showed statistically significant variation, corroborating assertions that the activities of nursing care, undertaken directly or indirectly, as measured by the instrument, can change depending on the patient's degree of dependence, on the complexity of the illness, on the institution's characteristics, and on the organization and work processes of the team. ${ }^{2,19}$

The differences found in comparing the NAS in the different Assistential Sites emphasize the importance of having an extra nursing technician as a 'floater', to meet the demands posed by whichever Site has the greatest workload, and to reduce the occurrence of possible adverse events which are directly related to the work overload and failures in the care process. ${ }^{12}$

One study undertaken in an intensive care unit in Spain also presented a difference in the NAS when this was compared between three different groups of patients. The authors conclude that the results help one to investigate the needs of each group in order to adequately allocate and plan the work. ${ }^{8}$

Measuring the NAS in each Assistential Site can organize the work process in this ICU and adjust the composition of the nursing team, taking into account the different characteristics of the patients - contributing to the quality of the care and to the patient's safety ${ }^{12,19}$ - considering, furthermore, that increasing the workload by one patient per nurse increases the probability of a patient dying within 30 days by $7 \% .^{5}$

In this regard, on evidencing the actual number of human resources necessary for the nursing work, the nurse must mobilize strategies for developing new care practices, to the detriment of the practices usually used for managing human resources as adopted in hospitals, in which all the patients are assisted as if they needed the same care.

In this same axis, it is known that the organization of the work environment and the appropriate composition of the team can result in professional satisfaction and reduce the chances of the team members presenting burnout - which can compromise the safety of the care. ${ }^{5,15}$ In the present study, this unit used the strategy of Assistential Sites to respond to these needs. This organization of the work process is currently used in this ICU, and is a strategy recognized by the entire multi-professional team.

As a limitation of this study, it is emphasized that the study was carried out in a single institution, with a sample made up of patients from one unit - and this condition must be considered in generalizing from the results. In this regard, it is suggested that further studies be carried out, considering different aspects of ICU in order to broaden the possibilities for clinical actions and for research for Nursing.

\section{CONCLUSION}

The study showed that patients with shorter length of stay in ICU, and those who did not survive, contributed to increasing the workload in ICU.

The differences found in comparing the NAS in the different Assistential Sites, particularly between the Isolation and the Long Stay Sites in the months of July and August, and between the Long Stay and Postoperative Sites in September, showed that the activities of nursing care can change, depending on the patient's degree of dependence, on the complexity of the disease, on the characteristics of the institution, and on the organization and work processes of the team.

Comparing the NAS in the different groups of patients at each Assistential Site made it possible to organize the work process of the nursing team in the ICU, contributing to the safety of the team and of the patient. 


\section{REFERENCES}

1. Ministério da Saúde (BR). Portaria №.3432, de 12 de agosto de 1998. Estabelece critérios de classificação entre diferentes Unidades de Tratamento Intensivo - UTI [Internet]. Brasília; 1998. [cited 2017 Jan 20] Available from: http://bvsms.saude.gov.br/bvs/saudelegis/gm/1998/ prt3432_12_08_1998.html

2. Altafin JAM, Grion CMC, Tanita MT, Festti J, Cardoso LTQ, Veiga CFF, et al. Nursing Activities Score e carga de trabalho em unidade de terapia intensiva de hospital universitário. Rev Bras Ter Intensiva [Internet]. 2014 Jul/Sept; [cited 2017 Nov 8]; 26(3):292-8. Available from: http://www.scielo.br/scielo.php?script=sci_arttext\&pid=S0103507X2014000300292. DOI: 10.5935/0103-507X.20140041

3. Lachance J, Douville F, Dallaire C, Padillha KG, Gallani MC. The use of the Nursing Activities Score in clinical settings: an integrative review. Rev Esc Enferm USP [Internet]. 2015 Dec; [cited 2017 Nov 8]; 49(n.spe):147-56. Available from: http://www.scielo.br/scielo. php?script=sci_arttext\&pid=S0080-62342015000700147. DOI: http:// dx.doi.org/10.1590/S0080-623420150000700021

4. Ferretti-Rebustini REL, Nogueira LS, Silva RCG, Poveda VB, Machado SP, Oliveira EM, et al. Aging as a predictor of nursing workload in Intensive Care Unit: results from a Brazilian Sample. Rev Esc Enferm USP [Internet]. 2017 Apr; [cited 2017 Nov 8]; 51:e03216. Available from: http://www.scielo.br/scielo.php?script=sci_arttext\&pid =S0080-62342017000100412. DOI: http://dx.doi.org/10.1590/S1980220X2016036903216

5. Aiken LH, Sloane DM, Bruyneel L, Van den Heede K, Griffiths P, Busse R, et al. Nurse staffing and education and hospital mortality in nine European countries: a retrospective observational study. Lance [Internet]. 2014 May; [cited 2017 Jul 7]; 383(9931):1824-30. Available from: http://www.thelancet.com/pdfs/journals/lancet/PIIS0140 6736(13)62631-8.pdf

6. Miranda DR, Nap R, de Rijk A, Schaufeli W, lapichino G;TISS Working Group. Therapeutic Intervention Scoring System. Nursing activities score. Crit Care Med [Internet]. 2003 Feb; [cited 2017 Nov 8]; 31(2):37482. Available from: https://www.ncbi.nlm.nih.gov/pubmed/12576939. DOI: 10.1097/01.CCM.0000045567.78801.CC

7. Reich R, Vieira DFVB, Lima LB, Rabelo-Silva ER. Carga de trabalho em unidade coronariana segundo o Nursing Activities Score. Rev Gaúcha Enferm [Internet]. 2015 Jul/Sep; [cited 2017 Nov 8]; 36(3):2835. Available from: http://www.scielo.br/scielo.php?pid=S198314472015000300028\&script=sci_arttext\&tIng=pt. DOI: http://hdl handle.net/10183/129818.

8. Carmona-Monge FJ, Jara-Pérez A, Quirós-Herranz C, Rollán-Rodríguez G, Cerrillo-González I, García-Gómez S, et al. Assessment of nursing workload in three groups of patients in a Spanish ICU using the Nursing Activities Score scale. Rev Esc Enferm USP [Internet]. 2013 Apr; [cited 2017 Nov 8]; 47(2):335-40. Available from: http://www.scielo.br/scielo. php?pid=S0080-62342013000200009\&script=sci_arttext\&tlng=en DOI: http://dx.doi.org/10.1590/S0080-62342013000200009

9. Queijo AF, Padilha KG. Nursing Activities Score (NAS): adaptação transcultural e validação para a língua portuguesa. Rev Esc Enferm USP [Internet]. 2009 Dec; [cited 2017 Nov 8]; 43(n.espe):1018-25. Available from: http://www.scielo.br/scielo.php?script=sci_arttext\&pid =S0080-62342009000500004.DOI: http://dx.doi.org/10.1590/S008062342009000500004
10. Stafseth SK, Solms D, Bredal IS. The characterisation of workloads and nursing staff allocation in intensive care units: a descriptive study using the Nursing Activities Score for the first time in Norway. Intensive Crit Care Nurs [Internet]. 2011 Oct; [cited 2017 Nov 8]; 27(5):290-4. Available from: https://www.ncbi.nlm.nih.gov/pubmed/21871805. DOI: 10.1016/j.iccn.2011.07.003

11. Padilha KG, Stafseth S, Solms D, Hoogendoom M, Monge FJC, Gomaa $\mathrm{OH}$, et al. Nursing Activities Score: an updated guideline for its application in the Intensive Care Unit. Rev Esc Enferm USP [Internet]. 2015 Dec [cited 2017 Nov 8]; 49(n.espe):131-7. Available from: http://www.scielo. br/scielo.php?script=sci_arttext\&pid=S0080-62342015000700131. DOI: http://dx.doi.org/10.1590/S0080-62342009000500004

12. Oliveira AC, Garcia PC, Nogueira LS. Nursing workload and occurrence of adverse events in intensive care: a systematic review. Rev Esc Enferm USP [Internet]. 2016 Jul/Aug; [cited 2017 Nov 8]; 50(4):679-89. Available from: http://www.scielo.br/scielo.php?script=sci_arttext\&pid =S0080-62342016000400683. DOI: http://dx.doi.org/10.1590/S0080623420160000500020

13. Castro MCN, Dell'Acqua MCQ, Corrente JE, Zornoff DCM, Arantes LF Aplicativo informatizado com o Nursing Activities Score: Instrumento para gerenciamento da assistência em unidade de terapia intensiva. Texto Contexto Enferm [Internet]. 2009 Jul/Sep; [cited 2017 Nov 8]; 18(3):577-85. Available from: http://www.scielo.br/scielo. php?script=sci_arttext\&pid=S0104-07072009000300022. DOI: http:// dx.doi.org/10.1590/S0104-07072009000300022

14. Conselho Nacional de Saúde (BR). Resolução № 466 de 12 de dezembro de 2012. Estabelece Diretrizes e Normas Regulamentadoras de Pesquisas Envolvendo Seres Humanos. Brasília (BR): Ministério da Saúde; 2012.

15. Nogueira LS, Koike KM, Sardinha DS, Padilha KG, Sousa RMC Carga de Trabalho de enfermagem em unidades de terapia intensiva públicas e privadas. Rev Bras Ter Intensiva [Internet]. 2013 Jul/Sep; [cited 2017 Nov 8]; 25(3):225-32. Available from: http://www.scielo.br/ scielo.php?script=sci_arttext\&pid=S0103-507X2013000300225. DOI: 10.5935/0103-507X.20130039

16. Nogueira LS, Ferretti-Rebustini REL, Poveda VB, Silva RCG, Barbosa $R L$, Oliveira EM, et al. Carga de trabalho de enfermagem: preditor de infecção relacionada à assistência à saúde na terapia intensiva? Rev Esc Enferm USP [Internet]. 2015; [cited 2017 Nov 8]; 49(n.espe):3642. Available from: http://www.scielo.br/scielo.php?pid=S008062342015000700036\&script=sci_abstract\&tlng=pt. DOI: http://dx.doi. org/10.1590/S0080-623420150000700006.

17. Lucchini A, De Felippis C, Elli S, Schifano L, Rolla F, Pegoraro F, et al Nursing Activities Score (NAS): 5 years of experience in the intensive care units of an Italian University hospital. Intensive Crit Care Nurs [Internet]. 2014 Jul; [cited 2017 Nov 8]; 30(3):152-8. Available from: https://www.ncbi.nlm.nih.gov/pubmed/24370275. DOI: http://dx.doi. org/10.1016/j.iccn.2013.10.004

18. Cyrino CMS, Dell'Acqua MCQ. Sítios assistenciais em Unidade de Terapia Intensiva e relação do nursing activities score com a infecção hospitalar. Esc Anna Nery [Internet]. 2012 Oct/Dec; [cited 2017 Nov 8]; 16(4):712-8. Available from: http://www.scielo.br/scielo. php?script=sci_arttext\&pid=S1414-81452012000400010. DOI: http:// dx.doi.org/10.1590/S1414-81452012000400010

19. Swiger PA, Vance DE, Patrician PA. Nursing workload in the acutecare setting: A concept analysis of nursing workload. Nurs Outlook [Internet]. 2016 May/Jul; [cited 2017 Nov 8]; 64(3):244-54. Available from: https://www.ncbi.nlm.nih.gov/pubmed/26944266. DOI: http:// dx.doi.org/10.1016/j.outlook.2016.01.003 